\title{
A double blind trial of amoxycillin in the treatment of gonorrhoea
}

\author{
R. N. THIN, M. A. E. SYMONDS, ElIZABETH J. SHAW, AND J. WONG \\ St Bartholomew's Hospital and Medical College, and Eastern Hospital, London \\ P. K. HOPPER ${ }^{1}$ AND B. SLOCOMBE ${ }^{2}$ \\ Hackney Hospital Laboratory, London ${ }^{1}$, and \\ Beecham Pharmaceuticals, Chemotherapeutic Research Centre, Brockham Park, Betchworth, Surrey ${ }^{2}$
}

SUMmARY A double blind comparison of two regimens of amoxycillin plus probenecid in the treatment of uncomplicated anogenital gonorrhoea is reported. Forty-three $(86.0 \%)$ of 50 patients treated with $1 \mathrm{~g}$ amoxycillin plus $1 \mathrm{~g}$ probenecid and followed-up for 14 days were regarded as cured, and $51(94.4 \%)$ of 54 patients treated with $3 \mathrm{~g}$ amoxycillin plus $1 \mathrm{~g}$ probenecid were regarded as cured. Fifty-nine per cent of 69 isolates of Neisseria gonorrhoeae were sensitive to amoxycillin (minimum inhibitory concentration $\leqslant 0.05 \mathrm{mg} / \mathrm{ml}$ ). Although there was no statistical difference between the results of the two regimens it is concluded that the larger dose of amoxycillin plus probenecid is required where only $60 \%$ of gonococci are sensitive to amoxycillin.

\section{Introduction}

Amoxycillin is a semi-synthetic penicillin which was released for clinical use in the United Kingdom in 1972 (Sutherland et al., 1972). Its chemical structure and activity are similar to ampicillin (Sutherland et al., 1972), it is not affected by gastric acid, and peak concentrations two hours after ingestion are double those of an equivalent dose of ampicillin (Croydon and Sutherland, 1970).

There are a number of reports on amoxycillin for the treatment of uncomplicated gonorrhoea in this country (Alergant, 1973; Willcox, 1974; Price and Fluker, 1975) and rather more in the United States of America (see for example, Journal of Infectious Diseases Supplement, June 1974). In all these studies either a single regimen was used, or comparison was made without any 'blind' element. We therefore decided to undertake a double blind trial of two single dose regimens of amoxycillin given by mouth with probenecid. The lower dose was $1 \mathrm{~g}$ amoxycillin plus $1 \mathrm{~g}$ probenecid, chosen because Alergant (1973) in Liverpool reported better results with this regimen than with $1 \mathrm{~g}$ amoxycillin alone. In London, Price and Fluker (1975) reported satisfactory results with $3 \mathrm{~g}$ amoxycillin alone so this

Address for reprints: Dr R. N. Thin, Department of Genital Medicine, St Bartholomew's Hospital, London EC1A 7BE

Received for publication 16 November 1976 plus $1 \mathrm{~g}$ probenecid was chosen as the other dose in the trial.

The results obtained with these two regimens form the subject of this paper.

\section{Methods}

Men and women with uncomplicated anogenital gonorrhoea attending the Department of Genital Medicine, St Bartholomew's Hospital, and the associated Homerton Grove Clinics, Eastern Hospital, were admitted to the study. All cases presenting during the study period (6 October 1975 to 19 March 1976) were included except patients hypersensitive to penicillin, travellers unable to attend for followup, patients in whom syphilis was suspected, and patients attending the Eastern Hospital on Friday afternoons (whose cultures could not reach the laboratories within the same period as samples taken from the rest of the cases).

In men presumptive diagnosis was made by microscopical identification of typical Gram-negative intracellular diplococci in smears taken from the urethra or rectum (using a proctoscope). Material was also taken on charcoal impregnated swabs and placed in Stuart's medium for transport to the laboratory. In women material for microscopy and culture was taken from the urethra and cervix. Gram stains were made and read in the clinics by experienced nurses. 
Material for culture was plated on to the medium described by Riddell and Buck (1970). Although it was planned to carry out all cultures in one laboratory using materials from one source, some results from a second laboratory had to be used. These were obtained from duplicate specimens and the methods were the same, apart from the use of nystatin in the culture medium instead of pimafucin. Neisseria gonorrhoeae were identified by colonial appearance, oxidase reaction, Gram stain appearance, and by sugar fermentation reactions using serum-free medium (Flynn and Waitkins, 1972).

For antibiotic sensitivity tests oxidase-positive colonies were subcultured on to $10 \%$ horse blood agar (Oxoid, Blood Agar Base CM55). After 18 hours' incubation, cells were washed from the agar slope and $0.001 \mathrm{ml}$ of a broth suspension of approximately $10^{5} \mathrm{cfu} / \mathrm{ml}$ was inoculated on to $10 \%$ horse blood agar plates containing serial dilutions of antibiotic using a multiple inoculation device. The plates were read after 18 hours' incubation at a temperature of $37^{\circ} \mathrm{C}$ in candle jars. The Oxford strain of Staphylococcus aureus was included as a control.

The manufacturers made up $1 \mathrm{~g}$ and $3 \mathrm{~g}$ doses of amoxycillin in identical tablets which were packed individually in a random order unknown to the clinic staff. Each patient was given a dose of amoxycillin plus $1 \mathrm{~g}$ probenecid and swallowed it under supervision in the clinic. The same batch of probenecid was used in both clinics.

Patients were asked to return one, seven, and 14 days after treatment when they were questioned about symptoms and sexual contact. The same Gram stains and cultures as those taken before treatment were repeated in all cases at all visits, and men also had their urine examined by the two-glass test.

Treatment was considered to have failed when gonococci reappeared within 14 days in a patient who emphatically denied further contact. Reinfection was considered to be the cause when gonococci reappeared within the 14-day period in a patient who admitted further contact.

\section{Results}

Ninety-seven patients were treated with the regimen containing amoxycillin $1 \mathrm{~g}$ and 100 patients were treated with the regimen containing amoxycillin $3 \mathrm{~g}$. The age distribution and countries of origin were similar in the two groups. More men than women were treated with the $3 \mathrm{~g}$ regimen than with the $1 \mathrm{~g}$ regimen.

Forty-three $(86.0 \%)$ of 50 patients treated with the $1 \mathrm{~g}$ regimen and followed-up for 14 days were regarded as cured and $51(94.4 \%)$ of 54 patients treated with the $3 \mathrm{~g}$ regimen were cured (Table 1). The difference between these results is not significant $\left(\chi_{1}^{2}=1 \cdot 27, p>0 \cdot 05\right)$. Probable reinfection occurred in three patients treated with $1 \mathrm{~g}$ and in five patients treated with $3 \mathrm{~g}$ amoxycillin. Detailed results for men and women are shown in Table 2. The most striking difference was the result for both regimens in women and this is almost statistically significant (Fisher's Exact Test $\mathbf{P}=\mathbf{0} \cdot 0533$ ). There were no significant differences in the results when assessed by race. Positive culture results were obtained before and after treatment in all cases of failure.

Successful antibiotic sensitivity tests were obtained from only 69 isolates and the results are shown in Table 3. Results were obtained from only two cases of treatment failure. Both were treated with the $1 \mathrm{~g}$ regimen; one had a minimum inhibitory concentration (MIC) of $0.1 \mu \mathrm{g}$ amoxycillin $/ \mathrm{ml}$ and in the other it was $0.2 \mu \mathrm{g} / \mathrm{ml}$.

Table 1 Results of treatment in patients followed-up for 14 days

\begin{tabular}{llc}
\hline & \multicolumn{2}{l}{ Amoxycillin dose } \\
\cline { 2 - 3 } Result & $1 \mathrm{~g}$ & $3 \mathrm{~g}$ \\
\hline Cure & $43(86 \cdot 0)$ & $51(94 \cdot 4)$ \\
Failure & $7(14 \cdot 0)$ & $3(5 \cdot 6)$ \\
Reinfection & 3 & 5 \\
Defaulted & 44 & 41 \\
Total & 97 & 100 \\
\hline
\end{tabular}

Percentages are given in parentheses.

Table 2 Results of treatment in men and women

\begin{tabular}{llc}
\hline & \multicolumn{2}{l}{ Amoxycillin dose } \\
\cline { 2 - 3 } Result & $1 \mathrm{~g}$ & $3 \mathrm{~g}$ \\
\hline Men & & \\
Cure & $25(92 \cdot 6)$ & $32(91 \cdot 4)$ \\
Failure & $2(7 \cdot 4)$ & $3(8 \cdot 6)$ \\
Reinfection & 2 & 4 \\
Defaulted & 31 & 32 \\
Total & 60 & 71 \\
& & \\
Women & $18(78 \cdot 3)$ & $19(100)$ \\
Cure & $5(21 \cdot 7)$ & -1 \\
Failure & 1 & 9 \\
Reinfection & 13 & 29 \\
Defaulted & 37 & \\
Total & & \\
\hline
\end{tabular}

Fisher's Exact Test $P=0.0533$.

Percentages are given in parentheses.

\section{Discussion}

The cure rate of $86 \%$ with $1 \mathrm{~g}$ amoxycillin plus $1 \mathrm{~g}$ probenecid is unsatisfactory, and the cure rate of $94.4 \%$ with $3 \mathrm{~g}$ amoxycillin plus $1 \mathrm{~g}$ probenecid is barely satisfactory when compared with the widely 
Table 3 Antibiotic sensitivity results of 69 strains of N. gonorrhoeae

\begin{tabular}{|c|c|c|c|c|c|c|c|c|}
\hline \multirow[b]{2}{*}{ Regimen } & \multicolumn{8}{|c|}{ MIC levels $\mu \mathrm{g} / \mathrm{ml}$} \\
\hline & $000 \cdot 5$ & 0.01 & 0.02 & 0.05 & $0 \cdot 1$ & 0.2 & 0.5 & $1 \cdot 0$ \\
\hline \multicolumn{9}{|l|}{ Penicillin } \\
\hline $\begin{array}{l}\text { no. } \\
\% \\
\text { cum \% }\end{array}$ & $\begin{array}{l}7 \\
(10 \cdot 1) \\
10\end{array}$ & $\begin{array}{l}31 \\
(44 \cdot 9) \\
55\end{array}$ & $\begin{array}{l}13^{*} \\
(18 \cdot 8) \\
74\end{array}$ & $\begin{array}{l}1 \\
(1 \cdot 4) \\
75\end{array}$ & $\begin{array}{l}5 \\
(7 \cdot 2) \\
83\end{array}$ & $\begin{array}{l}5 \\
(7 \cdot 2) \\
90\end{array}$ & $\begin{array}{l}5 \\
(7 \cdot 2) \\
97\end{array}$ & $\begin{array}{l}2 \\
(2 \cdot 9) \\
100\end{array}$ \\
\hline \multicolumn{9}{|l|}{ Ampicillin } \\
\hline $\begin{array}{l}\text { no. } \\
\% \\
\text { cum \% }\end{array}$ & - & $\begin{array}{l}4 \\
(5 \cdot 8) \\
6\end{array}$ & $\begin{array}{l}22 \\
(31 \cdot 9) \\
38\end{array}$ & $\begin{array}{l}18^{*} \\
(26 \cdot 1) \\
64\end{array}$ & $\begin{array}{l}6 \\
(8 \cdot 7) \\
72\end{array}$ & $\begin{array}{l}16 \\
(23 \cdot 2) \\
96\end{array}$ & $\begin{array}{l}3 \\
(4 \cdot 3) \\
100\end{array}$ & - \\
\hline \multicolumn{9}{|l|}{ Amoxycillin } \\
\hline $\begin{array}{l}\text { no. } \\
\%\end{array}$ & $\begin{array}{l}1 \\
(1 \cdot 4)\end{array}$ & $\begin{array}{l}5 \\
(7 \cdot 2)\end{array}$ & $\begin{array}{l}13 \\
(18 \cdot 8)\end{array}$ & $\begin{array}{l}22^{*} \\
(31 \cdot 9)\end{array}$ & $\begin{array}{l}8 \\
(11 \cdot 6)\end{array}$ & $\begin{array}{l}16 \\
(23 \cdot 2)\end{array}$ & $\begin{array}{l}4 \\
(5 \cdot 8)\end{array}$ & - \\
\hline cum $\%$ & 1 & 7 & 28 & 59 & 71 & 94 & 100 & \\
\hline
\end{tabular}

*MIC values for $S$. aureus Oxford strain.

accepted minimum of $95 \%$. However, as Table 1 shows, there was a high defaulter rate which tends to lower the cure rate. Of the strains studied $75 \%$ were sensitive to penicillin (MIC $\leqslant 0.05 \mu \mathrm{g} / \mathrm{ml}$ ) and $59 \%$ were sensitive to amoxycillin (MIC $\leqslant 0.05$ $\mu \mathrm{g} / \mathrm{ml})$. The two patients who failed, and from whose pre-treatment cultures MICs were obtained, both harboured gonococci with reduced penicillin sensitivity.

These clinical results are less satisfactory than those of Alergant (1973) who reported a 94.2\% cure rate among 138 patients treated with $1 \mathrm{~g}$ amoxycillin plus $1 \mathrm{~g}$ probenecid and followed-up for 14 days. Seventy per cent of strains were regarded as sensitive to penicillin (MIC $\leqslant 0.06 \mu \mathrm{g} / \mathrm{ml}$ ) but amoxycillin sensitivity studies were not reported.

Price and Fluker (1975) treated 97 men and 65 women using $3 \mathrm{~g}$ amoxycillin without probenecid and claimed cure rates of $99 \%$ in men and $95 \%$ in women assessed at the first follow-up visit. They presented antibiotic sensitivity results in a manner which does not allow comparison with the current series. When our results of treatment are analysed in the same way the cure rate with the $1 \mathrm{~g}$ regimen is $96.3 \%$ and with $3 \mathrm{~g}$ it is $97 \cdot 6 \%$.
St Bartholomew's Hospital serves a commuter population and the Homerton Grove Clinics serve a local population. The proportion of penicillinsensitive isolates reported here was similar to the proportion reported by Taylor and Seth (1975) from the London Hospital which serves an adjoining local population and part of the same commuter population.

We believe that this is one of the first reports of a double blind trial in the treatment of gonorrhoea. This gives greater weight to our conclusion that in an area where only $60 \%$ of the gonococci have an MIC of amoxycillin $\leqslant 0.05 \mu \mathrm{g} / \mathrm{ml}$ then $1 \mathrm{~g}$ amoxycillin plus $1 \mathrm{~g}$ probenecid is probably too small a dose and $3 \mathrm{~g}$ amoxycillin plus $1 \mathrm{~g}$ probenecid are required for satisfactory results in the treatment of uncomplicated gonorrhoea.

This work was supported in part by a grant from Bencard Ltd. Dr K. M. Bridgeman kindly arranged the supply of amoxycillin and Jackie Urwin carried out the statistical analysis. We thank the staff of the two clinics for their hard work.

\section{References}

Alergant, C. D. (1973). Treatment of gonorrhoea with amoxycillin British Journal of Venereal Diseases, 49, 274-276.

Croydon, E. A., and Sutherland, R. (1970). $\alpha$ amino-p-hydroxybenzylpenicillin (BRL 2333), a new semisynthetic penicillin: absorption and excretion in man. Antimicrobial Agents and Chemotherapy, $10,427-430$.

Flynn, J., and Waitkins, S. A. (1972). A serum-free medium for testing fermentation reactions in Neisseria gonorrhoeae. Journal of Clinical Pathology, 25, 525-527.

Journal of Infectious Diseases (1974). 129, S250-S266.

Price, J. D., and Fluker, J. L. (1975). Amoxycillin in the treatment of gonorrhoea. British Journal of Venereal Diseases, 51, 398-400.

Riddell, R. H., and Buck, A. C. (1970). Trimethoprim as an additional selective agent in media for the isolation of $N$. gonorrhoeae. Journal of Clinical Pathology, 23, 481-483.

Sutherland, R., Croydon, E. A. P., and Rolinson, G. N. (1972). Amoxycillin: a new semi-synthetic penicillin. British Medical Journal, 3, 13-16.

Taylor, P. K., and Seth, A. D. (1975). Ampicillin plus probenecid compared with procaine penicillin plus probenecid in the treatment of gonorrhoea. British Journal of Venereal Diseases, 51, 183-187.

Willcox, R. R. (1974). Effective treatment of gonorrhoea in London with two oral doses of amoxycillin. British Journal of Venereal Diseases, 50, 120-124. 